\title{
The Outer Membrane of Methylobacterium organophilum
}

\author{
By IAN C. HANCOCK* AND KATHERINE M. WILLIAMS \\ Department of Microbiology, The Medical School, University of Newcastle upon Tyne, \\ Framlington Place, Newcastle upon Tyne NE2 4HH, UK
}

(Received 29 August 1985; revised 14 November 1985)

\begin{abstract}
Inner and outer membranes were isolated from Methylobacterium organophilum by sucrose density centrifugation after disruption of bacteria by shaking with glass beads. The outer membrane (OM) contained all the pink oxocarotenoid pigment of the cell and unusually small amounts of phospholipid and lipopolysaccharide. An unidentified glucan was present in both membrane fractions. Several major OM proteins had molecular sizes in the range $49 \mathrm{kDa}$ to $80 \mathrm{kDa}$ and most of the OM proteins remained insoluble when $\mathrm{OM}$ or cell wall was treated with $2 \%(\mathrm{w} / \mathrm{v})$ sodium dodecyl sulphate (SDS) at temperatures up to $50^{\circ} \mathrm{C}$. Neither polysaccharide nor phospholipid was solubilized under the same conditions. Increasing the concentration of methanol in the growth medium led to an increase in the bacterial phospholipid content and to increased solubility of the OM in $2 \%$ SDS. It is suggested that the resistance of the OM to solubilization by the detergent is due in part to the presence of large amounts of three unidentified polar, phosphate-free lipids that might be related to hopane polyols. Phospholipids in isolated walls and $\mathrm{OM}$ were rapidly degraded by endogenous phospholipase when incubated in Tris buffer at $\mathrm{pH} 8$ but the unidentified lipids were retained in the particulate fraction.
\end{abstract}

\section{INTRODUCTION}

Methylotrophic bacteria utilize carbon sources for growth, such as methane, methanol and methylated amines, that would be expected to interact with hydrophobic domains of the cell envelope and disrupt membrane structure (Chin \& Goldstein, 1984). Merabtine et al. (1982) found that the pink facultative methylotroph Pseudomonas extorquens grew at progressively reduced rates in concentrations of methanol up to $6 \%(\mathrm{v} / \mathrm{v})$ but little information is available on the sensitivity of Gram-negative bacteria in general towards methanol. Many species are resistant to concentrations of ethanol up to about $5 \%(\mathrm{v} / \mathrm{v})$. Escherichia coli, for example, can grow at reduced rates in ethanol concentrations of up to $10 \%$ (Ingram \& Buttke, 1984). The toxicity of alcohols towards most bacteria increases sharply with increasing size and hydrophobicity of the alkyl group of the alcohol (Ingram \& Buttke, 1984). However, some methylotrophs can oxidize readily and remain viable in the presence of higher alkanes, aldehydes and a wide range of primary and secondary alcohols (Dalton, 1980; Hanson, 1980; Haber et al., 1983; Hou et al., 1980) and the products of these reactions are usually found outside the cell. This property of methylotrophs has been investigated widely for its commercial potential (Haber et al., 1983; Higgins et al., 1980).

In the best studied Gram-negative bacteria the outer membrane (OM) is a permeability barrier to hydrophobic substances (Nikaido, 1979). If that is true of methylotrophs, diffusion of relatively hydrophobic substrates through the $\mathrm{OM}$ might be an important limiting factor in their uptake and utilization, and in the excretion of oxidized products. While active transport systems for methylamine have been found in the inner membranes (IM) of a number of bacteria (Bellion et al., 1983), methanol appeared to enter the cell by passive diffusion in Methylobacterium

Abbreviations: KDO, 2-keto-3-deoxyoctonate; IM, inner membrane(s); OM, outer membrane(s). 
(Pseudomonas) AM1 (Bellion et al., 1983). In this case modification of the cell envelope by osmotic shock increased the rate at which methanol was oxidized.

Little is known about the membranes of methylotrophs and how their structures might be adapted to the uptake of their unusual carbon sources. Methylotrophic bacteria develop intracytoplasmic membranes, particularly when grown on methane (Davies \& Whittenbury, 1970), but attempts to distinguish these from the IM have been unsuccessful (Cemina \& Trotsenko, 1980) and it appears that they are an extension of the IM. We report here the separation of the IM and OM of the pink facultative methylotroph Methylobacterium organophilum strain $\mathrm{XX}$ grown under conditions where intracytoplasmic membranes are not formed (Patt \& Hanson, 1978).

\section{METHODS}

Organism and growth conditions. Methylobacterium organophilum strain XX, a pink-pigmented facultative methylotroph (Patt et al., 1974), was obtained from Dr K. Powell, ICI Agricultural Division, Billingham, Cleveland, UK, and was maintained on plates of defined medium solidified with $1.5 \%$ (w/v) Oxoid Agar no. 3.

The defined medium contained, per litre, $20 \mathrm{ml}$ phosphate buffer, $\mathrm{pH} 6.8\left(95 \mathrm{~g} \mathrm{~K}_{2} \mathrm{HPO}_{4}\right.$ and $78 \mathrm{~g} \mathrm{NaH}_{2} \mathrm{PO}_{4}$ $\left.1^{-1}\right), 5 \mathrm{ml}$ ammonium sulphate stock solution $(36 \%, \mathrm{w} / \mathrm{v}), 0.5 \mathrm{ml}$ magnesium sulphate stock solution $(40 \%, \mathrm{w} / \mathrm{v})$ and $10 \mathrm{ml}$ of the trace elements solution of Cross \& Anthony (1980). Filter-sterilized methanol was added to the autoclaved medium to a final concentration of $0.5 \%(\mathrm{v} / \mathrm{v})$ unless otherwise stated. Fructose was sterilized separately and added, where indicated, to $0.5 \%(\mathrm{w} / \mathrm{v})$. Bacteria were grown at $30^{\circ} \mathrm{C}$ in $500 \mathrm{ml}$ batches of this medium in 2-litre flanged conical flasks, shaken at 200 r.p.m. in a Gallenkamp orbital incubator, or in 10 litres defined medium in a 15-litre fermenter (LH Engineering) with aeration at 10 litres $\mathrm{min}^{-1}$ and a stirring speed of 500 r.p.m. Polypropylene glycol was used as an antifoaming agent. Bacteria were harvested by centrifugation at $2{ }^{\circ} \mathrm{C}$.

Cell breakage and membrane preparation. All operations were done at $2{ }^{\circ} \mathrm{C}$. The harvested bacteria from 10 litres culture were washed once with $500 \mathrm{ml} 20 \mathrm{~mm}$-Tris $/ \mathrm{HCl}, \mathrm{pH} 8$, containing $0.1 \mathrm{M}-\mathrm{NaCl}$ and $10 \mathrm{~mm}$-methanol (Tris/ $\mathrm{NaCl}$ ) and were resuspended at $15 \%$ (wet $\mathrm{w} / \mathrm{v}$ ) in the same buffer. Batches $(50 \mathrm{ml})$ of the suspension were shaken with $30 \mathrm{ml}$ glass ballotini beads (no. 11) and one drop of antifoaming agent (polypropylene glycol) for 1.5 min at full speed in a Braun homogenizer cooled with carbon dioxide. Because of the size and shape of the cells, disruption was readily monitored by phase-contrast microscopy. Treatment under these conditions resulted in disruption of approximately $80 \%$ of the bacteria. Glass beads were removed by filtration and the broken cell suspension was centrifuged twice at $6000 \mathrm{~g}$ for $5 \mathrm{~min}$ to remove most of the unbroken cells. Cell wall material that formed a loose layer on top of the cell pellet was scraped off and recovered with the supernate. Cell walls were sedimented from the supernate by centrifugation at $48000 \mathrm{~g}$ for $15 \mathrm{~min}$, and washed twice with Tris/ $\mathrm{NaCl}$.

For the isolation of IM and OM the complete broken cell suspension was incubated for $5 \mathrm{~min}$ at $4{ }^{\circ} \mathrm{C}$ with lysozyme $\left(100 \mu \mathrm{g} \mathrm{ml}^{-1}\right)$ and ribonuclease $\left(10 \mu \mathrm{g} \mathrm{ml}^{-1}\right)$. The suspension was centrifuged at $200000 \mathrm{~g}$ max. for $1 \mathrm{~h}$ in a type $60 \mathrm{Ti}$ Beckman rotor and the sedimented material was washed twice in Tris/ $\mathrm{NaCl}$. Membrane fractions were separated by density gradient centrifugation in sucrose. The gradients were prepared in polycarbonate tubes and consisted of the following sucrose solutions (w/v), each containing $20 \mathrm{~mm}-\mathrm{Tris} / \mathrm{HCl}, 0.1 \mathrm{M}-\mathrm{NaCl}$ and $10 \mathrm{mM}-$ methanol, $\mathrm{pH} 8: 1 \mathrm{ml} 72 \%, 3 \mathrm{ml} 70 \%, 3 \mathrm{ml} 65 \%, 3 \mathrm{ml} 60 \%, 3 \mathrm{ml} 55 \%, 3 \mathrm{ml} 50 \%$ and $1 \mathrm{ml} 45 \%$. The gradients were allowed to equilibrate overnight at $2{ }^{\circ} \mathrm{C}$ before use. The membrane sample $(200000 \mathrm{~g}$ pellet) was suspended in $45 \%$ sucrose and $2 \mathrm{ml}$ samples, containing not more than $0.5 \mathrm{~g}$ (wet wt) membrane, were layered on top of the gradients and centrifuged at $150000 \mathrm{~g}$ for $16 \mathrm{~h}$ in a Beckman $60 \mathrm{Ti}$ rotor at $2{ }^{\circ} \mathrm{C}$. Fractions $(1 \mathrm{ml})$ were collected by pumping from the bottom of the tube. For the accurate measurement of the density of IM, the gradient consisted of the range of sucrose concentrations $64 \%$ to $40 \%(w / v)$ in the same sized steps as those in routine gradients. Densities were calculated from sucrose concentrations measured by refractometry, correcting for the presence of the buffer.

For further purification, the membrane band fractions were combined, diluted with Tris/ $\mathrm{NaCl}$ to $50 \mathrm{ml}$, and centrifuged at $200000 \mathrm{~g}$ for $60 \mathrm{~min}$. The pellets were resuspended in $45 \%(\mathrm{w} / \mathrm{v})$ sucrose in Tris/ $\mathrm{NaCl}$ and $2 \mathrm{ml}$ samples were layered on top of discontinuous gradients consisting of $2 \mathrm{ml} 51 \%, 8 \mathrm{ml} 58 \%$ and $2 \mathrm{ml} 77 \%(\mathrm{w} / \mathrm{v})$ sucrose in Tris $/ \mathrm{NaCl}$. The gradients were centrifuged at $150000 \mathrm{~g}$ max. for $16 \mathrm{~h}$ at $2{ }^{\circ} \mathrm{C}$.

Estimation of sucrose in membrane preparations. About $20 \mathrm{mg}$ (dry wt) membrane was suspended in $4 \mathrm{ml}$ water and heated in a boiling water bath for $15 \mathrm{~min}$. The residue was removed by centrifugation and the volume of the supernate was adjusted to $5 \mathrm{ml}$ with sodium acetate buffer $(0.5 \mathrm{M}$ in acetate), $\mathrm{pH} 4.5$. It was incubated with $\beta$ fructosidase (Boehringer; $15 \mathrm{U} \mathrm{ml}^{-1}$ ) for $3 \mathrm{~h}$ at $50^{\circ} \mathrm{C}$ and the glucose formed was measured using glucose oxidase and ABTS according to the Boehringer GOD-Perid procedure. Complete enzymic hydrolysis of sucrose in the samples was confirmed by the inclusion of measured amounts of sucrose as internal standards.

Treatment of cell wall and $O M$ with SDS. Cell wall or OM, isolated as described above, was resuspended in Tris $/ \mathrm{NaCl}$ at $15 \mathrm{mg}$ dry wt $\mathrm{ml}^{-1}$ and $0.1 \mathrm{ml}$ samples were mixed with $5 \mathrm{ml} 2 \%$ (w/v) SDS in Tris/ $\mathrm{HCl}$ buffer of 
various concentrations and $\mathrm{pH}$ values, with or without $5 \%(\mathrm{v} / \mathrm{v}) 2$-mercaptoethanol, as described in Results. The mixtures were incubated in a water bath at $40^{\circ} \mathrm{C}$ or $60^{\circ} \mathrm{C}$ for various periods, then cooled to room temperature and centrifuged at $48000 \mathrm{~g}$ for $15 \mathrm{~min}$ to recover insoluble wall material. The tubes were drained well and residual fluid was wiped out with tissue. The pellets were resuspended in electrophoresis sample buffer and heated at $100^{\circ} \mathrm{C}$ for $5 \mathrm{~min}$ before electrophoresis.

Extraction of polysaccharides with phenol. A broken cell suspension, purified OM or cell wall was treated with deoxyribonuclease, ribonuclease $\left(10 \mu \mathrm{g} \mathrm{ml}^{-1}\right.$ each) and glucoamylase $\left(50 \mu \mathrm{g} \mathrm{ml}^{-1}\right)$ in $20 \mathrm{mM}$-Tris/ $\mathrm{HCl}, 1 \mathrm{mM}$ $\mathrm{MgSO}_{4}$ for $30 \mathrm{~min}$ at $30^{\circ} \mathrm{C}$. Extraction with hot phenol was as described by Westphal \& Jann (1965). The aqueous phase of the phenol extract was freeze-dried after exhaustive dialysis against running tapwater and distilled water.

Hydrolysis of polysaccharide. Material obtained by phenol extraction was suspended in $0.5 \mathrm{M}-\mathrm{HCl}\left(100 \mathrm{mg} \mathrm{ml}^{-1}\right)$ and heated at $100^{\circ} \mathrm{C}$ for up to $2 \mathrm{~h}$. At intervals samples were removed and released lipid was extracted by the method of Bligh \& Dyer (1959). The extract was dried over anhydrous sodium sulphate and then taken to dryness by rotary evaporation under reduced pressure. The residue was dissolved in chloroform and examined by thinlayer chromatography (TLC) on plates (Merck) of silica gel G, $0.5 \mathrm{~mm}$ thick that had been prewashed with acetone and dried at room temperature. Elution was done in chloroform/methanol/water $(65: 25: 4$, by vol.). Lipids were detected on the dried plate by spraying with iodine $(0.5 \%, \mathrm{w} / \mathrm{v})$ in chloroform. Maximum release of lipid during hydrolysis was achieved in $1 \mathrm{~h}$ and this period of hydrolysis was used in subsequent experiments. The lipid extract was further hydrolysed in $6 \mathrm{M}-\mathrm{HCl}$ at $100^{\circ} \mathrm{C}$ for $4 \mathrm{~h}$ in sealed tubes under nitrogen. Free fatty acids were extracted by shaking with petroleum spirit (b.p. $40-60^{\circ} \mathrm{C}$ ) and retained for analysis. Acid was then removed from the aqueous phase by repeated rotary evaporation under vacuum in the presence of solid $\mathrm{NaOH}$. The final aqueous solution was used for detection of glucosamine in an automatic amino acid analyser (Jeol JLC-6AH). 2-Keto-3deoxyoctonate (KDO) in the polysaccharide was measured by the method of Karkhanis et al. (1978). Authentic KDO (Sigma) was used as standard. Total carbohydrate was estimated by the phenol/sulphuric acid method (Dubois et al., 1956) with glucose as standard. Hexosamines are not measured in this procedure.

Enzyme assays. Succinate dehydrogenase was estimated by measuring the reduction of 2,6-dichlorophenolindophenol in a phenazine methosulphate-coupled reaction (Bishop et al., 1967) and NADH oxidase was measured spectrophotometrically (Bishop et al., 1967). Methanol dehydrogenase was measured as described by Ghosh \& Quayle (1981). Phospholipase activity was measured as the average rate of decrease of endogenous lipid phosphorus over $30 \mathrm{~min}$ at $30^{\circ} \mathrm{C}$ when membrane was incubated at $45 \mathrm{mg}$ dry wt $\mathrm{ml}^{-1}$ in Tris/ $\mathrm{NaCl}, \mathrm{pH} \mathrm{8.0.}$ Protein was measured by the method of Bradford (1976) with bovine serum albumin as standard, or in an adaptation of this method for measurement of protein in electrophoresis sample buffer (Zaman \& Verwilghen, 1979).

Extraction and assay of lipids. Lipids were extracted from freeze-dried bacteria and membranes by the method of Bligh \& Dyer (1959) and non-lipid contaminants were removed on a column of Sephadex G-25 (Pharmacia; Wuthier, 1966). Extracts were dried by rotary evaporation followed by storage over $\mathrm{P}_{2} \mathrm{O}_{5}$ under vacuum overnight, and weighed. Drying was continued to constant weight. Phosphorus in lipids was measured by the method of Chen et al. (1956) and the weight of phospholipid was estimated as 24 times that of lipid phosphorus, based on the $M_{\mathrm{r}}$ of the predominant phospholipid species. Poly- $\beta$-hydroxybutyrate was measured by the method of Law \& Slepecky (1961).

One-dimensional TLC was done on silica gel G precoated on aluminium foil (Merck), without prior activation, in chloroform/acetic acid/methanol/water $(80: 15: 12: 4$, by vol.). The following stains were used: for phospholipids, the reagent of Dittmer \& Lester (1964); for lipids containing vicinal glycols, periodate-Schiff reagent (Baddiley et al., 1956); and for all lipids, charring at $150^{\circ} \mathrm{C}$ after use of the Dittmer-Lester reagent.

Analysis of fatty acids. Free fatty acids obtained from lipopolysaccharide (LPS) by acid hydrolysis, and phospholipids extracted by the method of Bligh \& Dyer (1959) were dissolved in $5 \mathrm{ml} 5 \%(\mathrm{v} / \mathrm{v}) \mathrm{H}_{2} \mathrm{SO}_{4}$ in methanol and heated in a sealed tube at $60^{\circ} \mathrm{C}$ for $3 \mathrm{~h}$. Water $(1 \mathrm{ml})$ was added to the cooled sample and fatty acid methyl esters were extracted into petroleum spirit (b.p. $40-60^{\circ} \mathrm{C}$ ). The extract was dried over anhydrous sodium sulphate and sodium hydrogen carbonate $(3: 1)$. Methyl esters were separated by gas chromatography on $5 \%(w / v)$ polyethylene glycol succinate at $160^{\circ} \mathrm{C}$ in a Packard model 427 gas chromatograph. Standard methyl esters of saturated and monounsaturated fatty acids (Sigma) and hydroxy fatty acids (Analabs) were used for comparison. When available, for identification of an individual peak, the appropriate standard methyl ester was cochromatographed with the unknown sample.

Sodium dodecyl sulphate-polyacrylamide gel electrophoresis (SDS-PAGE). Membrane proteins were separated by one-dimensional SDS-PAGE on $12 \%$ and $16 \%$ gels, $1.5 \mathrm{~mm}$ thick, in a discontinuous buffer system by the method of Laemmli (1970) at a constant $30 \mathrm{~mA}$ per gel, with water cooling. The gels were stained for protein with Coomassie Brilliant Blue R-250 (Weber \& Osborn, 1969). Protein molecular size markers were as follows: $a$ lactalbumin (14.2 kDa), soybean trypsin inhibitor (20.1 kDa), PMSF-treated trypsinogen (24 kDa), carbonic anhydrase $(29 \mathrm{kDa})$, glyceraldehyde 3 -phosphate dehydrogenase $(36 \mathrm{kDa})$, egg albumin $(45 \mathrm{kDa})$ and bovine serum albumin ( $66 \mathrm{kDa}$ ) (Sigma, 'Dalton Mark VII-L'). Carbohydrate-containing components were detected by 
staining with Schiff reagent after oxidation with periodic acid (Zacharius et al., 1969). Methanol dehydrogenase activity was detected on the gels by the method of Wadzinski \& Ribbons (1975) after proteins had been renatured by incubation of the gels for at least $1 \mathrm{~h}$ in the dark with $0.02 \mathrm{M}-\mathrm{Tris} / \mathrm{HCl}, \mathrm{pH} 8.0,10 \mathrm{mM}-\mathrm{MgCl}_{2}$ and $10 \mathrm{mM}-$ methanol, at room temperature.

Chemicals. Enzymes, coenzymes, KDO and dyes were obtained from Sigma. Acrylamide and $N, N-$ methylenebisacrylamide were products of Bio-Rad, and SDS 'specially pure', came from BDH. All other chemicals were 'Analar' grade from BDH.

\section{RESULTS}

\section{Membrane preparation and separation}

The procedure for the preparation of walls and membranes from $M$. organophilum is described in Methods. Shaking the bacteria with glass beads in a Braun homogenizer proved more effective than methods involving lysozyme-EDTA or ultrasound and led to rapid cell rupture $(>80 \%$ in $90 \mathrm{~s}$ ), permitting subsequent separation of the membranes. Inclusion of methanol in the buffer was essential for retention of methanol dehydrogenase activity. After removal of whole bacteria from the broken cell suspension, cell walls were sedimented as a bright pink pellet by centrifugation at $48000 \mathrm{~g}$ for $20 \mathrm{~min}$. Centrifugation of the supernate at $200000 \mathrm{~g}$ for $60 \mathrm{~min}$ yielded a further straw-coloured membrane pellet. The amount of this material was severely depleted if cell disintegration in the Braun homogenizer was taken to completion ( $3 \mathrm{~min}$ ). On density gradient centrifugation the $200000 \mathrm{~g}$ pellet gave a single band of buoyant density $\left(1.19 \mathrm{~g} \mathrm{ml}^{-1}\right)$ while the cell wall fraction gave a major pink band at $1.24 \mathrm{~g} \mathrm{ml}^{-1}$ and a trace of straw-coloured material at $1.19 \mathrm{~g} \mathrm{ml}^{-1}$. Further straw-coloured material of buoyant density $\left(1.19 \mathrm{~g} \mathrm{ml}^{-1}\right)$ was released from the pink cell wall fraction when it was incubated with lysozyme at $4{ }^{\circ} \mathrm{C}$. Maximum release occurred in $15 \mathrm{~min}$, and $80 \%$ of this took place over the first $5 \mathrm{~min}$. After $15 \mathrm{~min}$, pink material of density $1.22 \mathrm{~g} \mathrm{ml}^{-1}$, not sedimentable at $48000 \mathrm{~g}$, was also obtained. All fractions of buoyant density $1.19 \mathrm{~g} \mathrm{ml}^{-1}$ showed the same polypeptide pattern on SDS-PAGE. The pink fraction of density $1.22 \mathrm{~g} \mathrm{ml}^{-1}$ had the same polypeptide composition as wall sedimentable at $48000 \mathrm{~g}$ after $15 \mathrm{~min}$ treatment with lysozyme and differed markedly from the less dense fraction.

Chemical and enzymic analysis of the fractions derived from wall treated with lysozyme for $5 \mathrm{~min}$ (Table 1) and of the $200000 \mathrm{~g}$ pellet from the broken cell supernate, indicated that the material of lower buoyant density was IM containing most of the membrane-bound respiratory chain-linked enzymes succinate dehydrogenase, NADH oxidase and methanol dehydrogenase. The activity of succinate dehydrogenase was, however, very low. When bacteria were grown on fructose, succinate dehydrogenase had more than three times the specific activity of that of methanol-grown bacteria and the ratio of specific activities in IM and OM was 6 and the ratio for NADH oxidase was 9 . IM was completely soluble in boiling $4 \%$ SDS.

The wall fraction contained most of the LPS (measured as KDO), phospholipase, pink pigment and polysaccharide, and very little respiratory activity and thus probably consisted of a complex of OM and peptidoglycan. Treatment of this fraction with boiling $4 \%$ SDS left an insoluble residue representing $22 \%$ of its dry weight, which contained glucosamine and muramic acid. Incubation of the wall-OM complex with lysozyme for more than 15 min apparently released $\mathrm{OM}$ free of peptidoglycan and therefore of slightly lower density. After incubation with lysozyme for $6 \mathrm{~h}$ the wall-OM complex was entirely soluble in boiling $4 \%$ SDS.

Based on this study, the procedure described in Methods was adopted for routine preparation of $\mathrm{IM}$ and $\mathrm{OM}$ in which broken cells were treated with lysozyme for $5 \mathrm{~min}$ and then membranes were separated by sucrose density gradient centrifugation. While incubation with lysozyme for only $5 \mathrm{~min}$ left about $20 \%$ of the wall-attached IM contaminating the OM, this accounted for less than $4 \%$ of the total recoverable IM and represented less than $3 \%$ of the protein in the OM preparation. More extensive lysozyme treatment led to less contamination of OM by IM, but yielded less homogeneous $\mathrm{OM}$ and increased the risk of phospholipid degradation by endogenous phospholipase (see below). OM prepared from bacteria homogenized for $3 \mathrm{~min}$ in the Braun homogenizer, to give complete breakage, had an identical polypeptide composition to that produced by the standard procedure, so it is unlikely that incomplete breakage in the 
Table 1. Composition of membrane fractions isolated by density gradient centrifugation of broken bacteria after lysozyme treatment for $5 \mathrm{~min}$

The results are from one experiment, \pm the range of values in three separate experiments, and are the means of three replicate determinations, which differed by $<5 \%$.

\section{Component}

Membrane [mg (g dry wt cells) ${ }^{-1}$ ]

Protein*

Phospholipid*

Polysaccharide*

Total phosphorus*

KDO*

Succinate dehydrogenase $†$

NADH oxidase $\dagger$

Methanol dehydrogenase $\dagger$

Phospholipasef

Pink pigment $\left[A_{508}(\mathrm{mg} \text { lipid })^{-1} \mathrm{ml}^{-1}\right]$
Membrane fraction of density:

$\begin{array}{rr}1.24 \mathrm{~g} \mathrm{ml}^{-1} & 1 \cdot 19 \mathrm{~g} \mathrm{ml}^{-1} \\ 292 \pm 11 \% & 160 \pm 7 \% \\ 383 \pm 8 \% & 535 \pm 5 \% \\ 25 \pm 8 \% & 55 \pm 7 \% \\ 450 \pm 20 \% & 116 \pm 5 \% \\ 1.1 \pm 5 \% & 4.8 \pm 8 \% \\ 0.25 \pm 10 \% & 0.009 \pm 4 \% \\ 0 & 2.8 \\ 50 & 500 \\ 0 & 13.9 \\ 21 & 1 \\ 0.114 \pm 8 \% & 0.007 \pm 40 \%\end{array}$

* Expressed as $\mu \mathrm{g}$ (mg dry wt membrane) $)^{-1}$.

$\dagger$ Expressed as nmol product (mg protein) $)^{-1} \mathrm{~min}^{-1}$. The range of mean values for three separate membrane preparations was $\pm 7.5 \%$.

$\ddagger$ Decrease in lipid phosphorus, expressed as $\mu \mathrm{g} \mathrm{P}$ (mg protein) $)^{-1} \mathrm{~h}^{-1}$. The range of mean values for three separate membrane preparations was $\pm 12 \%$.

standard procedure disrupted a specific sub-population of the bacteria. Of the total cell lipid $74 \%$ was recovered in the two membrane fractions, allowing for incomplete breakage, but this should be regarded as an underestimate of the recovery of membrane protein, since some unavoidable loss of phospholipid due to endogenous phospholipase activity occurred during isolation (see below).

\section{Characteristics of the $O M$}

The OM was bright pink, due to the presence of a pigment soluble in chloroform, whose absorption spectrum had a maximum at $508 \mathrm{~nm}$ and inflections at $537 \mathrm{~nm}$ and $470-480 \mathrm{~nm}$, consistent with an oxocarotenoid structure (Downs \& Harrison, 1974). Some contamination with IM was indicated by the detection of NADH oxidase activity (Table 1) but several major IM polypeptides were completely undetectable in the OM (Fig. 1). The OM contained about 15 prominent proteins, separable by one-dimensional SDS-PAGE, several major ones of which had molecular sizes in the range $50 \mathrm{kDa}$ to $80 \mathrm{kDa}$ (Fig. 1).

\section{Solubility of $O M$ in $S D S$}

Most of the OM proteins were insoluble in $2 \%(\mathrm{w} / \mathrm{v}) \mathrm{SDS}, 10 \mathrm{mM}-\mathrm{Tris} / \mathrm{HCl}, \mathrm{pH} 8,40^{\circ} \mathrm{C}$ (Fig. 2) and at $50^{\circ} \mathrm{C}$ (not shown) even after incubation for $2 \mathrm{~h}$, the most prominent exceptions being the major components $\mathrm{c}$, $\mathrm{d}$ and e $(59,54.5$ and $53 \mathrm{kDa}), \mathrm{f}(49 \mathrm{kDa})$ and two minor proteins of 32.5 and $30.5 \mathrm{kDa}$. The insoluble material retained all the carotenoid pigment and at least $80 \%$ of its lipid and protein, suggesting that the integrity of the membrane was essentially unaltered. The SDS-insoluble protein profile of cell wall was indistinguishable from that of the SDS-insoluble fraction of OM. Heating in $2 \%$ SDS, pH 8 , at $60{ }^{\circ} \mathrm{C}$ solubilized most (about $95 \%$ ) of the wall protein and $80 \%$ of the phospholipid, as well as all the carotenoid pigment, but the insoluble residue selectively retained substantial proportions of three major OM proteins (bands $\mathrm{e}^{*}, \mathrm{~g}$ and 1; $52 \mathrm{kDa}, 45 \mathrm{kDa}$ and $21 \mathrm{kDa}$ ), a minor band, q, and smaller proportions of several others (Fig. 2). The presence of $5 \%(\mathrm{v} / \mathrm{v}) 2$-mercaptoethanol, as in electrophoresis sample buffer, had no general effect on solubilization. Solubilization of lysozyme-treated wall in electrophoresis sample buffer (pH 6.8, 2\% SDS, 5\% 2-mercaptoethanol) at different temperatures (Fig. 3) showed increasing general solubilization with increasing temperature between 30 and $60^{\circ} \mathrm{C}$. 


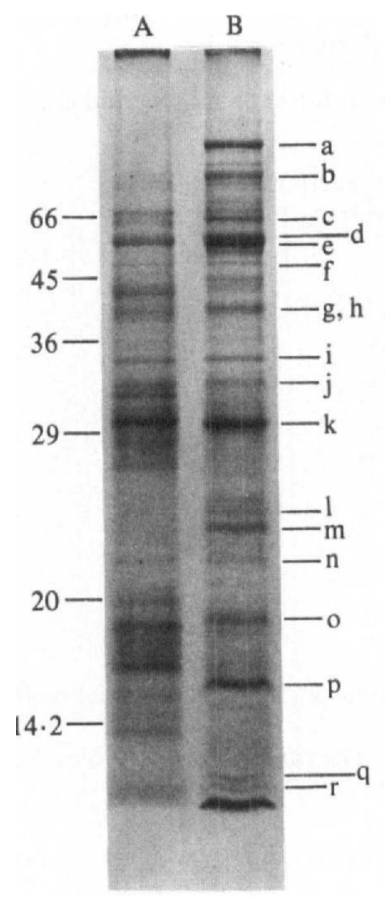

Fig. 1. Separation of membranes by sucrose density gradient centrifugation. SDS-PAGE of proteins from the two membrane fractions: lane A, low density fraction; lane B, high density fraction. Each sample contained $30 \mu \mathrm{g}$ protein. The positions of molecular size markers $(\mathrm{kDa})$ are shown on the left.

There was no further effect at temperatures up to $100^{\circ} \mathrm{C}$, even after heating for $30 \mathrm{~min}$, except that heating at $100^{\circ} \mathrm{C}$, but not $80^{\circ} \mathrm{C}$, led to the formation of a substantial amount of material that did not migrate further than the interface between the stacking and running gels during electrophoresis. No protein was detectable in the stacking gel from any of the samples. No heatmodifiable proteins were detected, with the possible exception of band $\mathrm{a}^{*}(82 \mathrm{kDa})$, which was not observed above $45^{\circ} \mathrm{C}$.

Electrophoresis of OM on $12 \%$ polyacrylamide gels consistently yielded a band staining with Coomassie Blue, at the leading edge of the gel. This component was retained by OM treated with SDS at $40{ }^{\circ} \mathrm{C}$ but was lost on treatment at $60^{\circ} \mathrm{C}$ (Fig. 2). On $16 \%$ polyacrylamide gels this material was resolved into two minor bands with molecular sizes between $12.5 \mathrm{kDa}$ and $6.5 \mathrm{kDa}$ and a broad, diffuse band of material equivalent to polypeptides in the molecular size range $2.8 \mathrm{kDa}$ to $3.3 \mathrm{kDa}$ that represented most of the small molecular size material. There was, however, no increase in the proportions of the small molecular size proteins when OM was treated with lysozyme $\left(100 \mu \mathrm{g} \mathrm{ml}^{-1}, 3 \mathrm{~h}, 30^{\circ} \mathrm{C}\right)$. Thus, no clear evidence was found for the presence of peptidoglycan-linked lipoprotein or its unbound form. The diffuse band of very small molecular size might have contained polypeptides formed by proteolysis during sample preparation, although the inclusion of EDTA, phenylmethylsulphonyl fluoride and benzamidine in all buffers as protease inhibitors did not affect the appearance of the band.

\section{Methanol dehydrogenase}

Measurement of methanol dehydrogenase activity in the membrane fractions and in the $200000 \mathrm{~g}$ supernate from broken cells indicated that, while the enzyme was predominantly soluble, $20 \%$ of the total activity was bound to the IM. The bound enzyme was retained by the membrane during washing and density gradient centrifugation and could be detected as a single band by activity staining of SDS-PAGE gels of IM proteins after removal of SDS. Its molecular size was in the range $60 \mathrm{kDa}$ to $65 \mathrm{kDa}$, consistent with the molecular size of $62 \mathrm{kDa}$ previously determined for the subunit of the soluble enzyme from this species of bacterium (Wolf \& Hanson, 1978). No methanol dehydrogenase was detected in OM. 


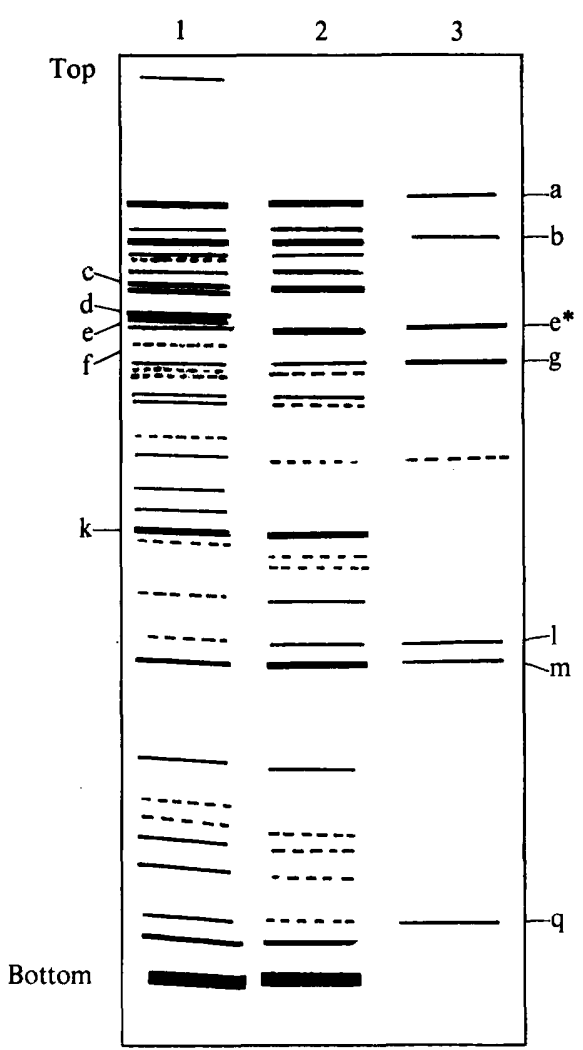

Fig. 2

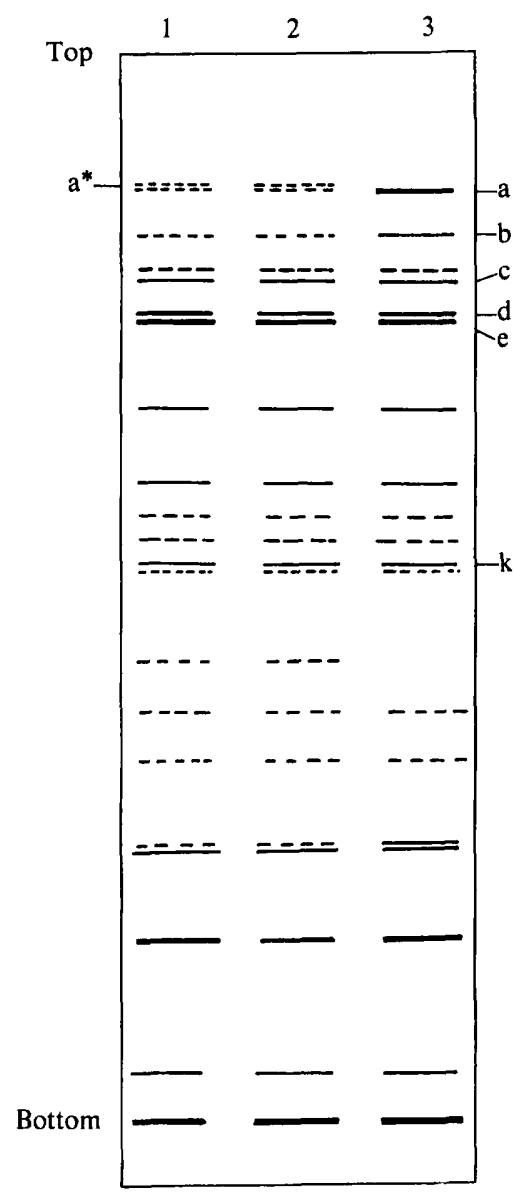

Fig. 3

Fig. 2. Tracing of SDS-PAGE gel of OM proteins insoluble in $2 \% \mathrm{SDS}$ at 40 and $60^{\circ} \mathrm{C}$. Lanes : $1, \mathrm{OM}$ $(120 \mu \mathrm{g}$ dry $\mathrm{wt}) ; 2$, insoluble residue from cell wall $(150 \mu \mathrm{g})$ treated with $2 \% \mathrm{SDS}, \mathrm{pH} 8,40^{\circ} \mathrm{C}$ for $30 \mathrm{~min} ; 3$, insoluble residue from wall $(150 \mu \mathrm{g})$ treated at $60^{\circ} \mathrm{C}$ as lane 2 . The thickness of the lines in the tracing indicates the relative intensities of staining with Coomassie Blue.

Fig. 3. Effect of temperature of solubilization on SDS-PAGE of OM proteins. OM was heated in sample buffer at various temperatures for $5 \mathrm{~min}$. Samples containing $120 \mu \mathrm{g}$ dry wt OM were applied to the gel. Samples were heated at $30^{\circ} \mathrm{C}$ (lane 1), $45^{\circ} \mathrm{C}$ (lane 2) and $60^{\circ} \mathrm{C}$ (lane 3). The thickness of the lines in the tracing indicates the relative intensities of staining.

\section{Carbohydrate content of the membranes}

Membrane preparations purified on sucrose gradients contained carbohydrate that could be extracted into boiling water, diffused through dialysis membrane and released glucose on treatment with $\beta$-fructosidase. It was concluded that this was sucrose. Exhaustive washing of the membranes with Tris/ $\mathrm{NaCl}$ at $4{ }^{\circ} \mathrm{C}$ did not remove the sucrose. It made up $12 \%$ of the dry wt of $\mathrm{OM}$, and $18 \%$ of the dry wt of IM. Quantitative measurements on these membranes have been corrected for the presence of sucrose, on the assumption that it came from the density gradients. The presence of firmly entrapped sucrose strongly suggested that both membrane preparations contained closed vesicles.

Polysaccharide, excluding nucleic acid, extracted into the aqueous phase with hot aqueous phenol, made up $45 \%(\mathrm{w} / \mathrm{v})$ of the $\mathrm{OM}$ and $11.6 \%$ of the $\mathrm{IM}$, as measured by the 
phenol/sulphuric acid method with glucose as standard. This technique would not measure peptidoglycan. When the broken cell suspension was incubated with glucoamylase (from Aspergillus oryzae; Sigma; $50 \mathrm{U} \mathrm{ml}^{-1}, 30 \mathrm{~min}$, room temp.) before isolation of the membranes, carbohydrate recovered in the aqueous phase of the phenol extracts fell to $5 \%(w / v)$ of the OM and to an insignificant level in the IM. This suggested the presence of a glucan in both membrane fractions, but it has not yet been characterized.

Material extracted by phenol from glucoamylase-treated OM contained $6 \mu \mathrm{g}$ KDO per mg polysaccharide as measured by the thiobarbituric acid method of Kharkanis et al. (1978). Dilute acid hydrolysis of this polysaccharide released a lipid extractable into chloroform/methanol, which yielded glucosamine and fatty acids after vigorous acid hydrolysis. The fatty acids were tentatively identified as palmitic (16:0), 2-hydroxydodecanoic (2-OH 12:0), 3-hydroxydodecanoic (3-OH 12:0) and 3-hydroxymyristic by gas chromatography of their methyl esters and extrapolation from data on authentic standards run under the same conditions. None of the hydroxyacids was found in the extractable lipids of the bacteria. It was concluded that the phenol-extractable polysaccharide included LPS, but the presence of additional polysaccharides, or an unusual LPS core structure, seemed likely in view of the very small amount of KDO detected.

When SDS-PAGE gels of OM treated with glucoamylase were stained for carbohydrate with the periodate-Schiff reagent, two bands were detected that just entered the running gel and ran slower than any of the detectable OM proteins. Phenol-extracted, glucoamylase-treated polysaccharide behaved in the same way on electrophoresis.

\section{Endogenous phospholipase in the $O M$}

Early attempts to measure the phospholipid content of isolated membranes gave inconsistent results, due to rapid hydrolysis of phospholipids when the bacteria were disrupted. When unwashed cell walls ( $48000 \mathrm{~g}$-sedimentable material from broken bacteria) were incubated at $30^{\circ} \mathrm{C}$, breakdown of phospholipid could be measured by the loss of phosphorus extractable into chloroform/methanol. Breakdown was faster in the absence of EDTA than with 5 mM-EDTA (Fig. 4), and did not occur in a suspension that had been heated at $100^{\circ} \mathrm{C}$ for $5 \mathrm{~min}$. TLC of extracted lipids showed complete breakdown of all the phospholipids in $60 \mathrm{~min}$, but only slight and very variable loss of three non-saponifiable, phosphate-free, periodate-Schiff-staining lipids, with $R_{F}$ values of $0.2,0.23$ and 0.25 (the $R_{F}$ of phosphatidyl glycerol was 0.54 ). No diglyceride or phosphatidic acid could be detected among the products by TLC. The breakdown thus appeared to be due to phospholipase A activity (Albright et al., 1973). This was located entirely in the wall-OM fraction (Table 1). Partly as a result of this lipid breakdown, only $74 \%$ $(w / v)$ of total cell lipid was recovered in the final membrane fractions, and the phospholipid contents of the fractions were low (Table 1), although the relative effects of the endogenous phospholipase activity on IM and OM during preparation could not be assessed. However, even in lipid extracts from whole bacteria, phospholipid made up only $36 \%(\mathrm{w} / \mathrm{v})$ of the total lipid extract free of water-soluble protein, excluding poly- $\beta$-hydroxybutyrate, and $1.5 \%$ of cell dry wt. Reproducible phospholipid contents were measured when the length of time taken for the steps in the preparation before membrane separation was minimized. Recoveries were approximately $10 \%$ higher if $5 \mathrm{mM}$-EDTA $\mathrm{Na}_{2}$ was included in the buffers, but EDTA was not used routinely because of its potential effect on membrane integrity.

OM incubated in Tris/ $\mathrm{NaCl}$ at $\mathrm{pH} 8,30^{\circ} \mathrm{C}$ for $3 \mathrm{~h}$ lost all detectable phospholipid, but all the protein remained sedimentable at $48000 \mathrm{~g}$ and showed the same polypeptide pattern on SDSPAGE as the starting material.

\section{Effects of methanol concentration in the growth medium}

Although $M$. organophilum was routinely grown in medium containing $0.5 \%(\mathrm{v} / \mathrm{v})$ methanol it grew without significant change in growth rate at concentrations of methanol up to $2 \%$ and at reduced rates in concentrations from 2 to $5 \%$, when inoculated from solid medium containing $0.5 \%$ methanol. Bacteria grown to the end of exponential phase in media with different methanol concentrations contained different amounts of phospholipid (Table 2), which 


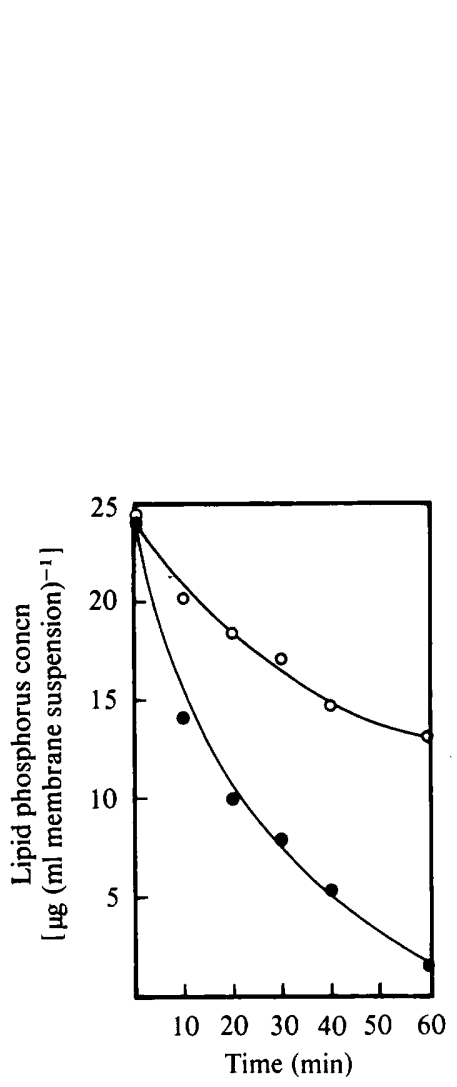

Fig. 4

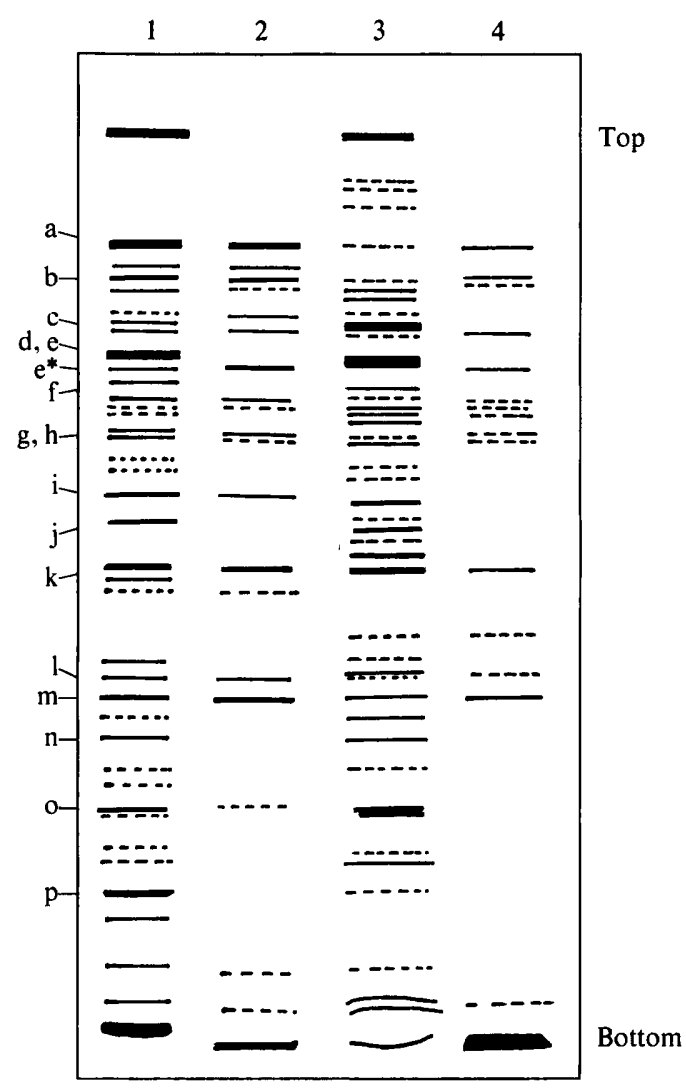

Fig. 5

Fig. 4. Degradation of wall phospholipids by endogenous phospholipase. Walls were prepared from $1.5 \mathrm{~g}$ (dry wt) bacteria as described in Methods, immediately resuspended in $10 \mathrm{ml} \mathrm{Tris} / \mathrm{NaCl}, \mathrm{pH} 8(O)$ or in the same buffer containing $5 \mathrm{~mm}$-EDTA $\mathrm{Na}_{2}(\mathrm{O})$, and incubated at $30^{\circ} \mathrm{C}$. At intervals, $2 \mathrm{ml}$ samples were taken and lipids extracted. The extracts were taken to dryness by rotary evaporation and redissolved in $1 \mathrm{ml}$ Bligh \& Dyer (1959) lower phase solvent mixture. Samples $(50 \mu \mathrm{l})$ were analysed for phosphorus.

Fig. 5. Effect of methanol concentration in growth medium on OM protein composition. SDS-PAGE was done on the following samples: OM $(150 \mu \mathrm{g}$ dry wt) of cells grown with $0.5 \%$ methanol (lane 1$)$ and $4 \%$ methanol (lane 3); material insoluble in $2 \% \mathrm{SDS}$ at $\mathrm{pH} 8,40{ }^{\circ} \mathrm{C}$ from OM $(150 \mu \mathrm{g})$ of cells grown with $0.5 \%$ methanol (lane 2$)$ and from OM $(600 \mu \mathrm{g})$ of cells grown with $4 \%$ methanol (lane 4$)$. The thickness of the lines on the tracing indicates the relative intensities of staining of the bands.

Table 2. Effect of concentration of methanol in medium on phospholipid content of bacteria

$\begin{array}{ccc}\begin{array}{c}\text { Methanol concn } \\ (\%, v / v) \\ 0.5\end{array} & \overbrace{\text { A }}^{\text {Yield* }} & \text { B } \\ 2.0 & 34.8 & 30 \cdot 8 \\ 4.0 & 33.1 & 35.1 \\ 6.0 & 22.7 & 19.3 \\ \text { (mg dry bacteria) }\end{array}$

\begin{tabular}{|c|c|}
\hline \multicolumn{2}{|c|}{$\begin{array}{c}\text { Lipid P† } \\
{\left[\mu \mathrm{g}(\mathrm{mg} \mathrm{cells})^{-1}\right]}\end{array}$} \\
\hline A & B \\
\hline 0.62 & 0.6 \\
\hline 0.89 & 0.9 \\
\hline 1.2 & 1.25 \\
\hline $1 \cdot 19$ & 1.07 \\
\hline
\end{tabular}

* Yield from $50 \mathrm{ml}$ culture at end of exponential growth.

+ Calculated from the mean of three phosphorus assays, which differed by less than $9 \%$. Results of two experiments (A and $B)$ are shown. 
increased with increasing methanol concentration. Comparison of the $\mathrm{OM}$ proteins from bacteria grown in media containing $0.5 \%$ and $4 \%$ methanol revealed differences both in the proportions of the different polypeptides and in their solubility in $2 \% \mathrm{SDS}$ at $40{ }^{\circ} \mathrm{C}$ (Fig. 5). Fig. 5 , lanes 2 and 4 show SDS-insoluble proteins from $150 \mu \mathrm{g}$ wall from $0.5 \%$ methanol and from $600 \mu \mathrm{g}$ wall from $4 \%$ methanol culture; in three separate experiments we consistently found that the OM proteins in the walls from bacteria grown in $4 \%$ methanol were much more soluble in SDS than those from bacteria grown in $0.5 \%$ methanol and proteins $\mathrm{a}, \mathrm{b}$ and o were present in much smaller quantities in the OM of bacteria grown at the higher methanol concentration. The polypeptide patterns of the IM preparations from the two cultures were almost identical.

\section{DISCUSSION}

The OM of $M$. organophilum had a number of unusual features. With the exception of three major proteins (c, $\mathrm{d}$ and e; Figs 1 and 2), and three minor ones, the $\mathrm{OM}$ was essentially insoluble in $2 \%$ SDS at temperatures up to $50{ }^{\circ} \mathrm{C}$. OM of several bacteria are resistant to $0.4 \%$ SDS (Hurlbert \& Gross, 1983) and a few OM proteins, including the porins, of enteric bacteria and pseudomonads remain associated with insoluble peptidoglycan in $2 \%$ SDS (Lugtenberg \& van Alphen, 1983), but in the latter case most of the phospholipid and LPS is extracted. Moreover, Schnaitman (1970) demonstrated that although the OM of $E$. coli appeared to be insoluble in Triton X-100, two-thirds of the phospholipid and half the LPS were solubilized by the detergent. In the case of $M$. organophilum, lipid and polysaccharide, as well as protein, were insoluble in SDS. Thus the OM of the methylotroph is an exceptionally tight association of lipid, protein and polysaccharide, together with peptidoglycan, and the contributions of the individual components to the strength of the association is unclear. Long incubation with lysozyme rendered the OM soluble in SDS, but this could not necessarily be attributed solely to degradation of peptidoglycan, since endogenous phospholipase activity would also have hydrolysed all the phospholipid of the membrane. Proteins of OM from bacteria grown in $4 \%$ methanol, which contained twice as much phospholipid as those grown at $0.5 \%$ methanol, were much more soluble in $2 \%$ SDS (Fig. 5), suggesting that the low concentration of phospholipid in the OM might contribute to its detergent resistance. The impermeability to hydrophobic antibiotics and resistance to long chain fatty acids and bile acid surfactants of many Gramnegative bacteria have been ascribed to the absence of phospholipid bilayer in the OM, and the presence of LPS in its outer leaflet (Nikaido, 1979; Sheu \& Freese, 1973).

The molecular sizes of several of the predominant OM proteins fell in the range $49 \mathrm{kDa}$ to $80 \mathrm{kDa}$. Such large molecular sizes for OM proteins have been found previously only in Caulobacter crescentus (Agabian \& Unger, 1978) and in the gliding bacteria Myxococcus xanthus (Orndorff \& Dworkin, 1980) and Lysobacter enzymogenes (von Tigerstrom \& Stelmaschuk, 1985). Major proteins in the molecular size range $30 \mathrm{kDa}-45 \mathrm{kDa}$, characteristic of $\mathrm{OM}$ from most of the bacteria that have been studied (Lugtenberg \& van Alphen, 1983), were absent from methanol-grown bacteria. Moreover, with the possible exception of protein $\mathrm{a}^{*}$, none of the OM proteins showed the resistance to denaturation in SDS that is characterized by heat modifiability of apparent molecular size. No evidence for the presence of a small molecular size peptidoglycan-linked lipoprotein was found, although relatively small amounts of two proteins of molecular size $<12 \mathrm{kDa}$ were present in OM both before and after treatment with lysozyme. The material that stained with Coomassie Blue as a diffuse band in the very small molecular size region of $16 \%$ polyacrylamide gels might have been lipid, which is known to stain with this dye.

As can be determined from the results of Goldberg \& Jensen (1977) for a number of type II methylotrophs that utilize methanol by the serine pathway, in $M$. organophilum phospholipids made up less than half of the total extractable cellular lipid, as indicated by measurement of total lipid phosphorus. On the other hand, Patt \& Hanson (1978) reported on the basis of gravimetric analysis of lipid classes separated by liquid chromatography on silicic acid that phospholipids made up over $90 \%$ of the total lipid. While differences in growth conditions might account for this discrepancy, another possibility is that a substantial proportion of the lipid consists of phosphate-free, very polar components that have not yet been identified. Three non- 
saponifiable lipids that did not contain phosphorus, were resistant to endogenous phospholipase activity and stained positively for vicinal glycol groups with the periodate-Schiff reagent were major components of the extractable lipids of whole cells and of IM and OM. Rohmer et al. (1984) reported that $M$. organophilum contained approximately $8 \mathrm{mg}$ hopanoid lipids per $\mathrm{g}$ (dry wt) bacteria, consisting mainly of a methyldiplopterol and various hopane polyols, and the same group have more recently described hopanetetrol ether-linked to amino derivatives of methyl cyclopentanols and glycosidically linked to glucosamine (Renoux \& Rohmer, 1985). Hopanoid lipids appear to be widely distributed among methylotrophic bacteria, with the exception of the closely related obligate methanol-utilizers 'Methylophilus methylotrophus' and 'Methylomonas clara' (Rohmer et al., 1984). Hopanoid lipids, like sterols, are known to reduce fluidity in the hydrophobic region of lipid bilayers (Bisseret et al., 1983) and therefore could reasonably be assumed to reduce the disordering effect of alcohols on the lipid regions of membranes, as does cholesterol (Chin \& Goldstein, 1984). Such a stabilizing role might be particularly important in a membrane whose lipids contained a very high proportion of unsaturated fatty acids, as in the case of $\boldsymbol{M}$. organophilum. The similarity in lipid composition of methylotrophic bacteria, which contain phosphatidyl choline (Goldberg \& Jensen, 1977; Patt \& Hanson, 1978), a very high proportion of unsaturated fatty acyl groups and lipids related to sterols, to the alcohol-tolerant yeast Saccharomyces cerevisiae is striking. It is possible that the glycol-containing lipids remaining in $M$. organophilum $\mathrm{OM}$ after digestion with endogenous phospholipase are hopane polyol derivatives, and that their presence in large quantities is responsible for the exceptional stability to detergent of these membranes. It may also be significant that the OM of ' $M$. methylotrophus', which is reported not to contain hopanoid lipids, is very sensitive to permeabilization by Tris and EDTA (Jones et al., 1982) unlike all other methanol-utilizing methylotrophs examined in this laboratory (unpublished work). The low phospholipid content and the small amount of detectable KDO-containing LPS in the OM of $M$. organophilum raises the questions of whether the membrane from methanol-grown bacteria contains any lipid or lipid/LPS bilayer, and where the large amount of polysaccharide is located in the membrane. These problems are now being investigated.

\section{REFERENCES}

Agabian, N. \& Unger, B. (1978). Caulobacter crescentus cell envelope: effect of growth conditions on murein and outer membrane protein composition. Journal of Bacteriology 133, 987-994.

Albright, F. R., White, D. A. \& Lennarz, W. J. (1973). Studies on enzymes involved in the catabolism of phospholipids in E. coli. Journal of Biological Chemistry 248, 3968-3977.

Baddiley, J., Buchanan, J. G., Handschumacher, R. E. \& PrescotT, J. F. (1956). Chemical studies in the biosynthesis of purine nucleotides. Part 1. The preparation of $\mathrm{N}$-glycylglycosylamines. Journal of the Chemical Society, 2818-2823.

Bellion, E., Kent, M. E., Aud, J. C., Alikhan, M. Y. \& BolBOT, J. A. (1983). Uptake of methylamine and methanol by Pseudomonas sp. strain AM1. Journal of Bacteriology 154, 1168-1173.

Bishop, D. G., Rutberg, L. \& SAMUelson, B. (1967). The solubilisation of the cytoplasmic membrane of Bacillus subtilis by sodium dodecylsulphate. European Journal of Biochemistry 2, 454-459.

Bisseret, P., Wolff, G., Albrecht, A. M., Tanaka, T., Nakatani, Y. \& Ourisson, G. (1983). A direct study of the cohesion of lecithin bilayers. The effect of hopanoids and alpha, omega-dihydroxycarotenoids. Biochemical and Biophysical Research Communications 110, 320-324.

BLIGH, E. G. \& DYER, W. J. (1959). A rapid method of total lipid extraction and purification. Canadian Journal of Biochemistry and Physiology 37, 911-917.

BRADFORD, M. M. (1976). A rapid and sensitive method for quantitation of protein utilising the principle of protein-dye binding. Analytical Biochemistry 72, 248-254.

Cemina, E. V. \& Trotsenko, Y. A. (1980). Isolation and identification of Methylomonas methanica membranes. Microbiology 49, 735-739.

Chen, P. S., Toribara, T. Y. \& Warner, H. (1956). Microdetermination of phosphorus. Analytical Chemistry 28, 1756-1761.

Chin, J. H. \& Goldstein, D. B. (1984). Cholesterol blocks the disordering effects of ethanol in biomembranes. Lipids 19, 929-935.

Cross, A. R. \& ANTHONY, C. (1980). The purification and properties of the soluble cytochromes $c$ of the obligate methylotroph Methylophilus methylotrophus. Biochemical Journal 192, 421-427.

Dalton, H. (1980). Oxidation of hydrocarbons by methane monooxygenases from a variety of microbes. Advances in Applied Microbiology 26, 71-87.

DAvies, S. L. \& WhitTenbury, R. (1970). Fine structure of methane and other hydrocarbon-utilizing bacteria. Journal of General Microbiology 61, 227232.

DitTmer, J. C. \& Lester, R. L. (1964). A simple, specific spray for the detection of phospholipids on 
thin-layer chromatograms. Journal of Lipid Research 5, 126-127.

Downs, J. \& HarRison, D. E. F. (1974). Studies on the production of pink pigment in Pseudomonas extorquens N.C.I.B. 9399 in continuous culture. Journal of Applied Bacteriology 37, 65-74.

Dubois, M., Gilles, K. A., Hamilton, J. K. \& Rebers, P. A. (1956). Colorimetric method for the determination of sugars and related substances. Analytical Chemistry 28, 350-356.

Ghosh, R. \& Quayle, J. R. (1981). Purification and properties of methanol dehydrogenase from Methylophilus methylotrophus. Biochemical Journal 199, 245-250.

Goldberg, I. \& Jensen, A. P. (1977). Phospholipid and fatty acid composition of methanol-utilising bacteria. Journal of Bacteriology 130, 535-537.

Haber, C. L., Allen, L. N., Zhao, S. \& Hanson, R. S. (1983). Methylotrophic bacteria: biochemical diversity and genetics. Science 221, 1147-1153.

HaNson, R. S. (1980). Ecology and diversity of methylotrophic organisms. Advances in Applied Microbiology 26, 3-39.

Higgins, I. J., Best, D. J. \& Hammond, R. C. (1980). New findings in methane-utilising bacteria highlight their importance in the biosphere and their commercial potential. Nature, London 286, 561-564.

Hou, C. H., Patel, R. N. \& Laskin, A. I. (1980). Epoxidation and ketone formation by $\mathrm{C}-1$ utilising microbes. Advances in Applied Microbiology 26, 4169.

Hurlbert, R. E. \& Gross, D. C. (1983). Isolation and partial characterization of the cell wall of Pseudomonas syringae pv. syringae HS191: comparison of outer membrane proteins of HS191 with those of two plasmidless derivatives. Journal of General Microbiology 129, 2241-2250.

INGRAM, L. O. \& BUtTKe, T. M. (1984). Effects of alcohols on microorganisms. Advances in Microbial Physiology 25, 254-296.

Jones, C. W., Kingsbury, S. A. \& Dawson, M. J. (1982). The partial resolution and dye-mediated reconstitution of methanol oxidase activity in Methylophilus methylotrophus. FEMS Microbiology Letters 13, 195-200.

Karkhanis, Y. D., Zeltner, J. Y., Jackson, J. J. \& CARLO, D. J. (1978). A new and improved microassay to determine KDO in the lipopolysaccharides of Gram-negative bacteria. Analytical Biochemistry 85, 595-601.

LAEMMLI, U.K. (1970). Cleavage of structural proteins during the assembly of the head of bacteriophage T4. Nature, London 227, 680-685.

LAW, J. H. \& SLEPECKY, R. A. (1961). Assay of poly- $\beta$ hydroxybutyric acid. Journal of Bacteriology 82, 3336.

LugtenberG, B. \& VAN ALPhen, L. (1983). Molecular architecture and functioning of the outer membrane of Escherichia coli and other Gram-negative bacteria. Biochimica et biophysica acta 737, 51-115.

Merabtine, H., Scott, C. D. B., HarRison, D. E. F. \& OLIVE, S. G. (1982). The role of pigmentation in the growth and survival of the methanol-utilising bacterium Pseudomonas extorquens. Journal of Chemical Technology and Biotechnology 32, 1059-1064.
NiKaIDO, H. (1979). Non-specific transport through the outer membrane. In Bacterial Outer Membranes, pp. 361-401. Edited by M. Inouye. New York: Wiley Interscience.

ORNDORFF, P. E. \& DWORKIN, M. (1980). Separation and properties of the cytoplasmic and outer membranes of vegetative cells of Myxococcus xanthus. Journal of Bacteriology 141, 914-927.

PATT, T. E. \& Hanson, R. S. (1978). Intracytoplasmic membrane, phospholipid and sterol content of Methylobacterium organophilum cells grown under different conditions. Journal of Bacteriology 134, 636-644.

Patt, T. E., Cole, G. C., Bland, J. \& Hanson, R. S. (1974). Isolation and characterisation of bacteria that grow on methane and organic compounds as sole sources of carbon and energy. Journal of Bacteriology 120, 955-964.

RenouX, J.-M. \& Rohmer, M. (1985). Prokaryotic triterpenoids. New bacteriohopanetetrol cyclitol ethers from the methylotrophic bacterium Methylobacterium organophilum. European Journal of Biochemistry 151, 405-410.

Rohmer, M., Bouvier-Nave, P. \& Ourisson, G. (1984). Distribution of hopanoid triterpenes in prokaryotes. Journal of General Microbiology 130, 1137-1150.

Schnaltman, C. A. (1970). Protein composition of the cell wall and cytoplasmic membrane of Escherichia coli. Journal of Bacteriology 104, 890-901.

Sheu, C. W. \& Freese, E. (1973). Lipopolysaccharide layer protection of Gram-negative bacteria against inhibition by long-chain fatty acids. Journal of Bacteriology 115, 869-875.

von Tigerstrom, R. G. \& Stelmaschuk, S. (1985). Localization of the cell-associated phosphatase in Lysobacter enzymogenes. Journal of General Microbiology 131, 1611-1618.

WADZINSKI, A. M. \& RiBbons, D. W. (1975). Oxidation of $\mathrm{Cl}$ compounds by particulate fractions of Methylococcus capsulatus: properties of methanol dehydrogenase and methanol oxidase. Journal of Bacteriology 122, 1364-1374.

WEBER, K. \& OSBORN, M. (1969). Reliability of molecular weight determinations by SDS-polyacrylamide gel electrophoresis. Journal of Biological Chemistry 244, 4406-4412.

WestPhaL, O. \& JANN, K. (1965). Bacterial lipopolysaccharides. Extraction with phenol-water and further applications of the method. Methods in Carbohydrate Chemistry 5, 83-91.

Wolf, H. J. \& Hanson, R. S. (1978), Alcohol dehydrogenase of Methylobacterium organophilum. Applied and Environmental Microbiology 36, 105-114.

WUTHIER, R. E. (1966). Purification of lipids from nonlipid contaminants on Sephadex bead columns. Journal of Lipid Research 7, 558-561.

ZachariUs, R. M., ZelL, T. E., MorRison, J. H. \& WoODLOCK, J. J. (1969). Glycoprotein staining following electrophoresis on acrylamide gels. Analytical Biochemistry 5, 148-152.

ZAMAN, Z. \& VerWILGHEN, R. L. (1979). Quantitation of proteins solubilised in sodium dodecylsulphatemercaptoethanol-Tris electrophoresis buffer. Analytical Biochemistry 100, 64-69. 